\title{
Article \\ GaInP/GaAs/poly-Si Multi-Junction Solar Cells by in Metal Balls Bonding
}

\author{
Ray-Hua Horng ${ }^{1,2, *}\left(\mathbb{D}\right.$, , Yu-Cheng Kao ${ }^{3}$, Apoorva Sood ${ }^{1}$, Po-Liang Liu ${ }^{3}{ }^{(0)}$, Wei-Cheng Wang ${ }^{3}$ and Yen-Jui Teseng ${ }^{3}$ \\ 1 Institute of Electronics, National Yang Ming Chiao Tung University, No. 1001, University Road, \\ Hsinchu 30010, Taiwan; apoorva07.eic08g@nctu.edu.tw \\ 2 Center for Emergent Functional Matter Science, National Yang Ming Chiao Tung University, No. 1001, \\ University Road, Hsinchu 30010, Taiwan \\ 3 Graduate Institute of Precision Engineering, National Chung Hsing University, No. 145, Xingda Road, \\ Taichung 40227, Taiwan; kaoyc@optorun.com.tw (Y.-C.K.); pliu@dragon.nchu.edu.tw (P.-L.L.); \\ g108067039@smail.nchu.edu.tw (W.-C.W.); g108067033@smail.nchu.edu.tw (Y.-J.T.) \\ * Correspondence: rhh@nctu.edu.tw
}

Citation: Horng, R.-H.; Kao, Y.-C.; Sood, A.; Liu, P.-L.; Wang, W.-C.; Teseng, Y.-J. GaInP/GaAs/poly-Si Multi-Junction Solar Cells by in Metal Balls Bonding. Crystals 2021, 11, 726. https://doi.org/10.3390/ cryst11070726

Academic Editors: Chinho Park, M. Ajmal Khan and Dmitri Donetski

Received: 25 May 2021

Accepted: 22 June 2021

Published: 24 June 2021

Publisher's Note: MDPI stays neutral with regard to jurisdictional claims in published maps and institutional affiliations.

Copyright: (c) 2021 by the authors. Licensee MDPI, Basel, Switzerland. This article is an open access article distributed under the terms and conditions of the Creative Commons Attribution (CC BY) license (https:// creativecommons.org/licenses/by/ $4.0 /)$.

\begin{abstract}
In this study, a mechanical stacking technique has been used to bond together the $\mathrm{GaInP} / \mathrm{GaAs}$ and poly-silicon (Si) solar wafers. A GaInP/GaAs/poly-Si triple-junction solar cell has mechanically stacked using a low-temperature bonding process which involves micro metal In balls on a metal line using a high-optical-transmission spin-coated glue material. Current-voltage measurements of the GaInP/GaAs/poly-Si triple-junction solar cells have carried out at room temperature both in the dark and under 1 sun with $100 \mathrm{~mW} / \mathrm{cm}^{2}$ power density using a solar simulator. The GaInP/GaAs/poly-Si triple-junction solar cell has reached an efficiency of $24.5 \%$ with an open-circuit voltage of $2.68 \mathrm{~V}$, a short-circuit current density of $12.39 \mathrm{~mA} / \mathrm{cm}^{2}$, and a fill-factor of $73.8 \%$. This study demonstrates a great potential for the low-temperature micro-metal-ball mechanical stacking technique to achieve high conversion efficiency for solar cells with three or more junctions.
\end{abstract}

Keywords: mechanical stacking technique; GaInP/GaAs/poly-Si triple-junction solar cell; micrometal-ball

\section{Introduction}

It is well known that tandem-type III-V compound multi-junction solar cells possess the highest conversion efficiency when compared with solar cells fabricated using alternative absorbing materials. The practical six-junction (6J) inverted metamorphic multijunction (IMM) concentrator solar cell designs with a potential to exceed 50\% efficiency using moderately high quality junction materials has been proposed [1]. The current record efficiency of 6J IMM solar cell is $47.1 \%$ under 143 Suns concentration [2]. The high performance of these devices is due to mature epitaxial growth techniques and optimally designed current-matched tandem structures. A conversion efficiency over $30 \%$ has been achieved under the one-sun air mass 1.5 (AM1.5G) spectra condition using GaInP/GaAs/Ge (or InGaAs) triple-junction (TJ) solar cells [3-5]. However, this is too expensive to cost down the III-V solar cells because the underlying Ge substrate or InGaAs epilayer grown on InP substrate is very expensive compared to the cost of Si [6,7]. Furthermore, even the direct growth of 1.9-eV GaInP solar cells on Si by metalorganic chemical vapor phase deposition (MOCVD) is difficult due to different thermal expansion coefficients and a $4 \%$ lattice mismatch [6,7]. A graded SiGe buffer between the GaInP layer and the Si substrate has been demonstrated to enable lattice matching [6]. The SiGe buffer layer could play an important role in obtaining a high-quality current-matched cell to form a tandem dualjunction structure. Nevertheless, the efficiency is not high enough compared with that of a III-V solar cell grown on GaAs substrate [7-10].

Thus, the integration of III-V compound multi-junction solar cells and a Si solar cell by either direct wafer bonding or mechanical stacking have been extensively studied in order 
to develop photovoltaic devices with high photovoltaic conversion efficiencies [11-20]. These include AlGaAs-Si mechanically stacked solar cells by epoxy [21], mechanically stacked GaInP $\mathrm{P}_{2} / \mathrm{GaAs}$ dual junction cells on an InGaAs cell grown on an InP substrate by stacking holder [22], three-terminal GaAs/Si by conductive metal nanoparticle arrays [23] and four-terminal III-V///Si tandem cells with high efficiency by glue bonding [13]. Recently, the fabrication of III-V compound dual-junction (DJ) solar cells on silicon or on InGaAs/InP to form TJ solar cells by mechanical stacking and wire bonding [17] and threeterminal tandem on GaInP/Si by transparent conducting adhesive (TCA) [24] have been reported. A $46 \%$ efficiency was obtained with a 4 -junction solar cell using wafer bonding under concentrated sunlight [1]. Considering one sun AM1.5G conditions and using wafer bonding, a record of $38.8 \%$ with a five-junction stacking has also been obtained [3]. Nevertheless, the one-sun conversion efficiency of III-V/Si solar cells has been raised to $32.8 \%$ for two junctions and $35.9 \%$ for three junctions by using mechanical stacking technology [4]. In our previous results, the performance of III-V DJ bonded to Si to form a triple junction was better than that of III-V DJ bonded to InGaAs/InP due to the Si solar cell contributing to the high $\mathrm{V}_{\text {oc }}$ [17]. In order to connect the bottom cell and middle cell by wire, it is necessary to offer a larger area for the bottom cell. In the above study, it was found that the current was limited by the top DJ solar cell. It is well known that the cost of poly-Si solar cell is lower than that of single crystal Si solar cell. In order to further cost down, a poly-Si solar cell was used to evaluate the possibility of replacing the bottom single crystal Si solar cell. The electrical connection was evaluated to use in metal balls combined with transparent glue (KER 3000; Shin-Etsu Chemical Comp.) instead of the wire bonding which was fabricated in our previous publication. In general, glue-, metal-, and diffusion-bondings for the mechanical stacking technologies were used to fabricate the multi-junction solar cells [7,23-32]. The glue-bonding method is cheaper and easier, while the metal-bonding method requires determining the eutectic temperature. The diffusion-bonding method is relatively expensive owing to the high cost of processing equipment to support the technique. This study presents a new mechanical stacking fabrication method employing micro metal balls that are spun onto a metal line region using high-optical-transmission spin-coated glue material to bond the $\mathrm{GaInP} / \mathrm{GaAs}$ and poly-silicon solar cells. The fabrication processes and the optoelectronic performance of the fabricated solar cells using this new technique has been discussed in detail.

\section{Experiment}

In this study, GaInP/GaAs DJ solar cells were grown on $p$-type GaAs (100) substrates with 4" in diameter using MOCVD. The DJ solar cells were similar with that of our previous study [17] except growing the AlAs sacrificial layer on GaAs substrate for epitaxial lift-off (ELO). The poly-Si solar cell with $10 \mathrm{~cm} \times 10 \mathrm{~cm}$ was fabricated using a p-type poly-Si substrate, which was then implanted with $\mathrm{PH}_{3}$ and activated at $825^{\circ} \mathrm{C}$ to obtain a top n-layer with a thickness of $1 \mu \mathrm{m}$.

The size of the cell with $1.1 \mathrm{~mm} \times 1.1 \mathrm{~mm}$ was fabricated on 4" GaAs wafer. First, $\mathrm{AuGe} / \mathrm{Au}(50 / 120 \mathrm{~nm})$ electrodes were deposited on the $\mathrm{n}^{+}$-GaAs contact layer of GaInP/ GaAs DJ cells for front-side metal contact by thermal evaporation. Next, the exposure n++ $\mathrm{GaAs}$ layer was etched by $\mathrm{NH}_{4} \mathrm{OH}$ and $\mathrm{H}_{2} \mathrm{O}_{2}$ solution. This area was then deposited the $\mathrm{TiO}_{2}(54 \mathrm{~nm})$ and $\mathrm{MgF}_{2}(85 \mathrm{~nm})$ anti-reflection coating (ARC) by E-gun system. Following, the wafer was temporarily bonded to the glass with glue. The glue used was a thermal releasing type with a high optical transmission. The 4" GaAs substrate was subsequently removed using the ELO process [33]. After ELO processing, the surface of the epilayer of the DJ solar cells/glass was the GaInP etching stop layer. This layer was etched by $\mathrm{H}_{3} \mathrm{PO}_{4}: \mathrm{HCl}(1: 2)$ to expose the contact layer $\mathrm{p}^{+} \mathrm{GaAs}$. Then, a AuBe/Au $(50 \mathrm{~nm} / 100 \mathrm{~nm})$ metal line with a width of $20 \mu \mathrm{m}$ was deposited on the $\mathrm{p}^{+}$-GaAs contact layer by thermal evaporation to function as the backside electrodes. The processing flowchart of the DJ solar cells has also been shown in Figure 1. 


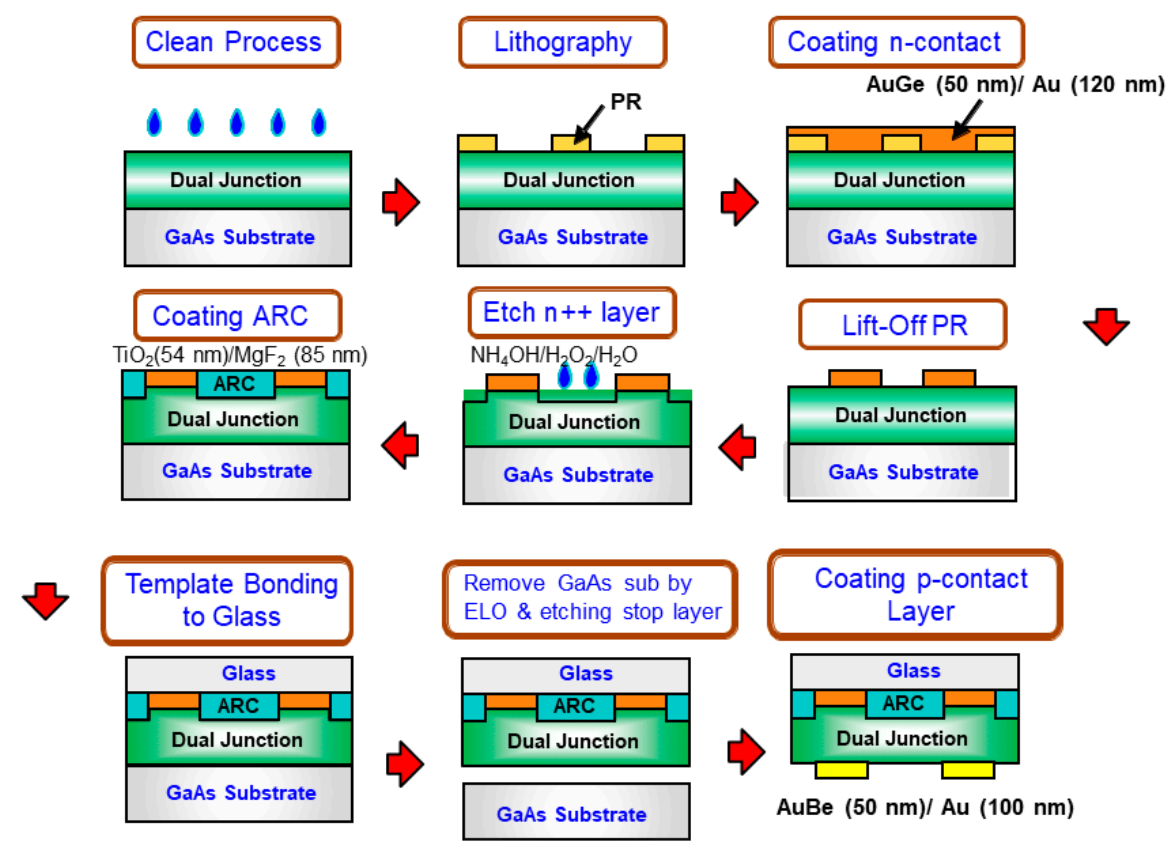

Figure 1. Processing flowchart of the DJ solar cells.

The schematic structures of the mechanical stacking solar cells are shown in Figure 2. In the case of the poly-Si solar cell, the front-side $\mathrm{Ni} / \mathrm{Al}$ metal line electrode $(50 \mathrm{~nm} / 2 \mu \mathrm{m})$ with a width of $20 \mu \mathrm{m}$ was deposited on the n-type $\mathrm{Si}$ top surface using an e-beam evaporator, and aluminum paste was coated on the back electrode via screen printing, shown in Figure 2b. The ARC did not be deposited on the Si solar cells. Subsequently, the GaInP/GaAs DJ solar cells were bonded onto the poly-silicon solar cells, shown in Figure 2a, via the mechanical stacking technique. First, micro metal indium (In) balls with $30 \mu \mathrm{m}$ diameter were spun on the electrode lines of a poly-Si solar cell. Here, the In balls will play an electrical connection between the DJ and poly-Si solar cells. Then, a high-opticaltransmission glue (KER 3000; Shin-Etsu Chemical Comp.) was coated by a spinner on the top-side of the DJ solar cell. Finally, the DJ GaInP/GaAs and poly-silicon solar cell were bonded together by mechanical pressure at $200{ }^{\circ} \mathrm{C}$ for one hour to form GaInP/GaAs on poly-Si triple-junction solar cells. Because, the viscosity of the glue was very low, it was easily squeezed out and this allowed the in metal balls to connect with the line electrodes of the DJ solar cell. Moreover, the GaInP/GaAs DJ solar cells were then temporarily bonded to the glass with glue. After the mechanical bonding, the temporarily bonded glue could be easily removed by a thermal process and the glass could be automatically separated from the III-V cells without damaging the cells. Finally, the discrete GaInP/GaAs / / poly-Si triple-junction solar cell has obtained after dicing, shown in Figure 2c. The DJ solar cell with GaAs substrate and poly-Si solar cell before bonding were also prepared for properties measurement.

The 3D structure about the In ball bonding was also shown in Figure 2d. The In ball distributed on the surface of $\mathrm{Si}$ solar cell was observed by optical microscope and shown in Figure 2e. Most of the In balls (red circles) assembled on the finger electrodes of the $\mathrm{Si}$ bottom cell observed by optical microscope. Partial In balls (blue circles) located on the Si surface. 
$\begin{array}{ll}\text { (a) Dual junction solar cell } & \text { (c) }\end{array}$

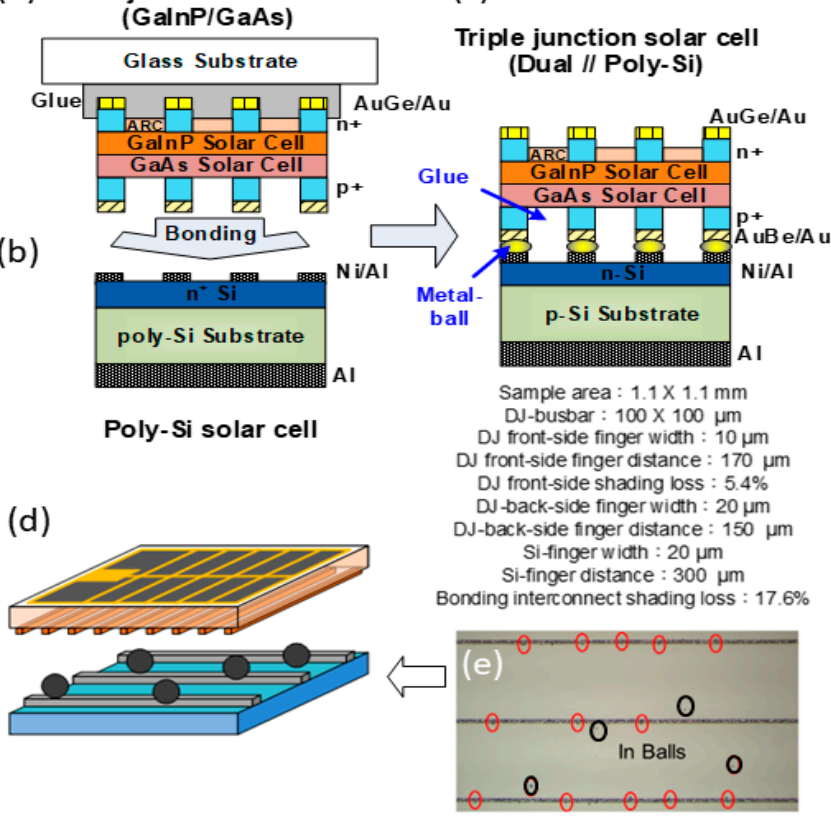

Figure 2. Schematic structure of (a) the GaInP/GaAs dual-junction, (b) poly-Si, and (c) GaInP/GaAs//poly-Si triple-junction solar cells. (d) 3D structure about the In ball bonding. (e) In Ball distributed on the surface of Si solar cell. Most of the In balls (red circles) assembled on the finger electrodes of the Si bottom cell observed by optical microscope. Partial In balls (blue circles) located on the Si surface.

A thin film GaInP/GaAs DJ epilayer bonded to glass (corning glass 1737) and silicone glue with $2 \mu \mathrm{m}$ coated on the corning glass were also prepared for the transmission measurement. The optical transmittance spectrum of the GaInP/GaAs DJ solar cell film and glue on the glass have been measured using a n\&k analyzer (model: 1280; N\&K Technologies). The illuminated current density-voltage $(\mathrm{J}-\mathrm{V})$ characteristics of the cell devices were investigated using a standard solar simulator (XES-40S1, San-Ei Electric) equipped with an AM1.5G light source $\left(100 \mathrm{~mW} / \mathrm{cm}^{2}\right)$ operated at room temperature. The solar simulator system was calibrated using a standard solar cell before sample measurement. The cell efficiency of solar cells was measured by the Institute of Nuclear Energy Research (INER), Atomic Energy Council of Taiwan. All the key equipment used for measurement and fabrication methods in this study have been listed in Table 1.

Table 1. All the key equipment used for measurement and fabrication methods in this study.

\begin{tabular}{ccc}
\hline Equipments & Fabrication & Measurement \\
\hline MOCVD & DJ solar cell structure growth & \\
\hline Photolithography & Pattern Fabrication & \\
\hline E-Gun Deposition & Electrode, ARC deposition & \\
\hline Wafer Bonding System & Stack Bonding & \\
\hline N\&k analyzer & & Tansmittance and Reflectance \\
\hline Solar Simulator & & J-V of Solar cells \\
\hline
\end{tabular}

\section{Results and Discussion}

The transmission characteristics of the GaInP/GaAs DJ epilayer and glue binder were important before bonding. The schematic of the measured structures and incident light direction are shown in the inset of Figure 3a. The transmission spectra of the GaInP/GaAs DJ epilayers and the silicone glue located on the glass substrate were measured in a 
wavelength range of 300-1100 nm, as shown in Figure 3a. It was found that the light was almost absorbed by the GaInP/GaAs DJ epilayers as the wavelength was shorter than $880 \mathrm{~nm}$. Concerning the transmittance of the silicone glue on the glass, this is higher than $80 \%$ as the wavelength is longer than $400 \mathrm{~nm}$. Although the transmission was not higher than $90 \%$, it could be higher than that of the glue/glass for real application due to the glass being removed for the real application and the glue become the thinner after the bonding. It is well known that the glue is easily damaged under the UV light radiation. In this work, the silicone glue layer was sandwiched by the GaInP/GaAs DJ epilayer and poly-Si solar cell for the real mechanical stacking solar cell application. Because the GaInP/GaAs DJ solar cell can effectively absorb the UV light, the glue could not be degraded by the UV light. Moreover, the reflectance of the DJ solar cell, before and after deposition of the ARC layers, were shown in Figure 3b. After the ARC deposition, the reflectivity reduced in the all measured wavelengths. The reflectance of the DJ solar cell without ARC deposition was high $(59 \%)$ as the wavelength was longer than $880 \mathrm{~nm}$. After ARC deposition, the reflectance can be reduced from $59 \%$ to $15 \%$ for the wavelength longer than $880 \mathrm{~nm}$. The ARC not only contributed to reduce the reflectivity in the wavelength absorbed by DJ solar cell, but also in the longer wavelengths $(>880 \mathrm{~nm})$.
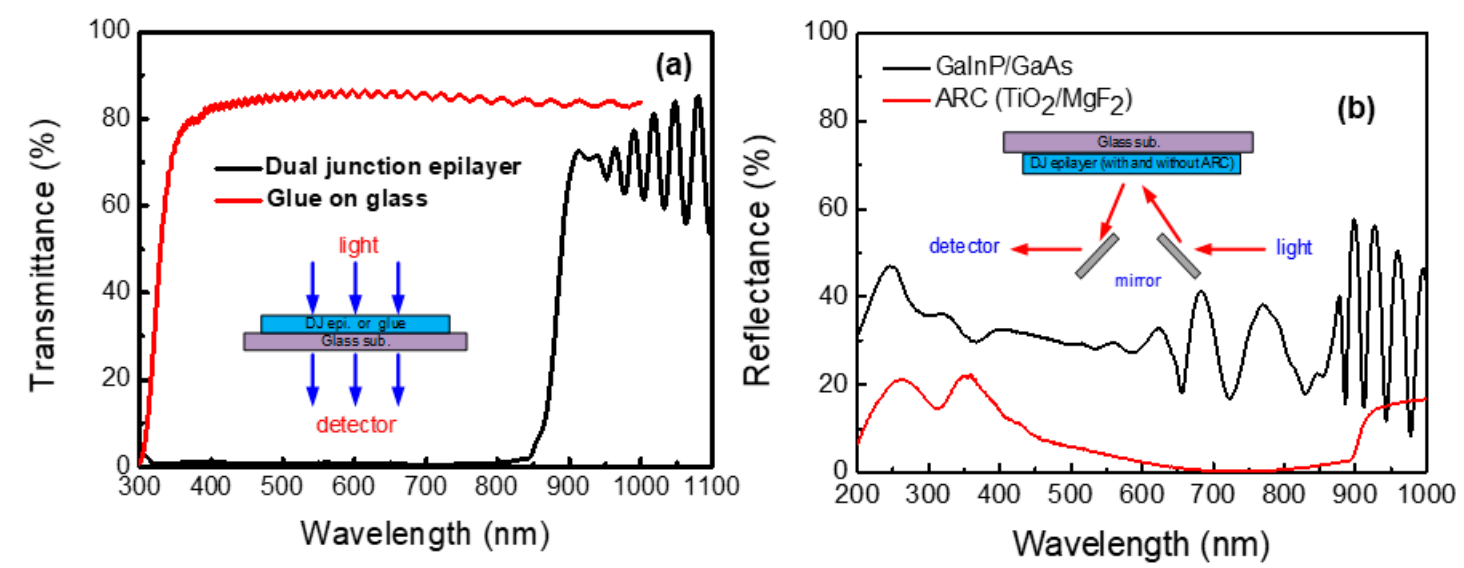

Figure 3. (a) Transmission spectra of the GaInP/GaAs dual-junction solar cell and glue on the glass substrate and (b) reflectance of DJ epilayer/glass with and without ARC.

Figure 4 shows the measured J-V characteristics of poly-Si, GaInP/GaAs DJ fabricated on GaAs substrate, and GaInP/GaAs/poly-Si TJ solar cells under a one-sun AM1.5G solar simulator. The corresponding conversion efficiency $(\eta)$, fill factor (FF), short-circuit current density $\left(\mathrm{J}_{\mathrm{sc}}\right)$, and open-circuit voltage $\left(\mathrm{V}_{\mathrm{oc}}\right)$ before and after mechanically stacking are summarized in Table 2. The $\mathrm{V}_{\text {oc }}$ values were $0.54,2.18$, and $2.68 \mathrm{~V}$ for the poly$\mathrm{Si}$, GaInP/GaAs DJ, and GaInP/GaAs/poly-Si TJ solar cells, respectively. The poly-Si, GaInP/GaAs DJ, and GaInP/GaAs/poly-Si TJ solar cells presented $\mathrm{J}_{\mathrm{sc}}$ values of 23.39, 13.03, and $12.39 \mathrm{~mA} / \mathrm{cm}^{2}$, respectively. The obtained $\mathrm{FF}$ values were $51.15 \%, 80.00 \%$, and $73.79 \%$ for the poly-Si, GaInP/GaAs DJ, and GaInP/GaAs/ / poly-Si TJ solar cells, respectively. It is worthy to mention that the $\mathrm{V}_{\mathrm{oc}}$ and $\mathrm{J}_{\mathrm{sc}}$ were changed after the bonding. The changed $\mathrm{V}_{\mathrm{oc}}$ was resulted from the solar cell being the $\mathrm{TJ}$ and $\mathrm{R}_{\mathrm{S}}$ and $\mathrm{R}_{\mathrm{p}}$ also changes after the bonding. The changed $\mathrm{J}_{\mathrm{sc}}$ was resulted from the current limitation by the DJ solar cell. These will be discussed in more details in the next paragraph. 


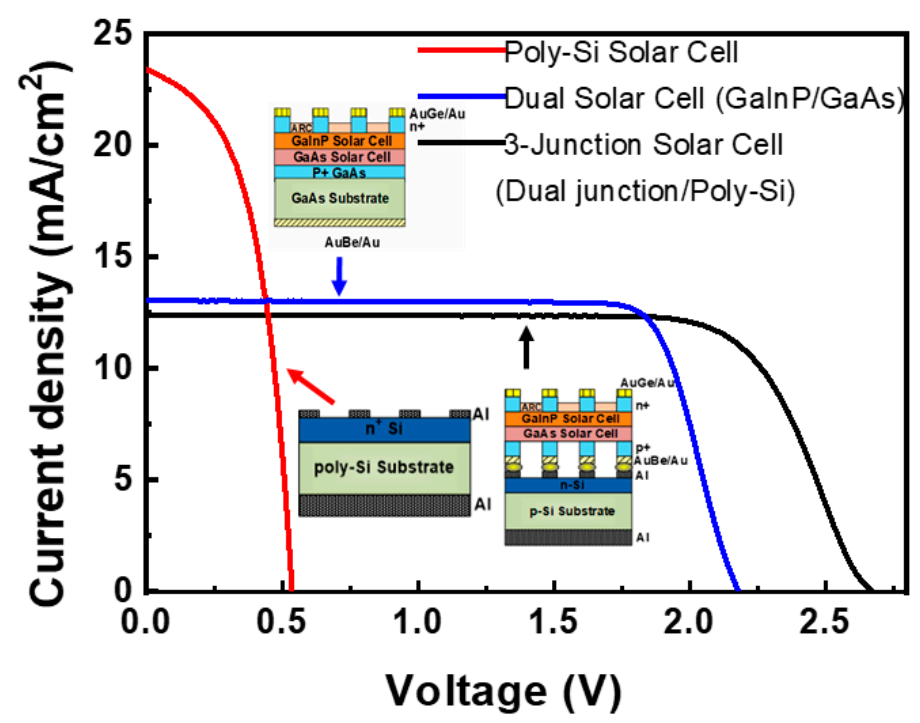

Figure 4. J-V characteristics of the GaInP/GaAs / / poly-Si triple-junction solar cell measured with the one-sun AM1.5G light source.

Table 2. Device characteristics of poly-Si, DJ solar cell and GaInP/GaAs/poly-Si triple-junction solar cells measured under 1 and 12 suns obtained from the J-V curve.

\begin{tabular}{ccccc}
\hline Type (@ One Sun) & $\mathbf{V}_{\mathbf{o c}}(\mathbf{V})$ & $\mathbf{J}_{\mathbf{s c}}\left(\mathbf{m A} \mathbf{A} \mathbf{c m}^{\mathbf{2}}\right)$ & $\mathbf{F F} \mathbf{( \% )}$ & $\boldsymbol{\eta} \mathbf{( \% )}$ \\
\hline Poly-Si solar cell & 0.54 & 23.39 & 51.15 & 6.46 \\
\hline DJ solar cell & 2.18 & 13.03 & 80.00 & 22.72 \\
\hline TJ solar cell & 2.68 & 12.39 & 73.79 & 24.50 \\
\hline
\end{tabular}

$\mathrm{V}_{\mathrm{oc}}$ : open-circuit voltage, $\mathrm{J}_{\mathrm{sc}}$ : short-circuit current density, FF: fill factor, $\eta$ : efficiency.

It was found that the $\mathrm{J}_{\mathrm{sc}}$ and $\mathrm{FF}$ values were decreased after the mechanical stacking. This could be resulted from the lower $\mathrm{J}_{\mathrm{sc}}$ associated with the bottom cell and the increased series resistance arising from the micro metal balls (indium) on the metal line region. This point can be demonstrated by a series resistance calculation [17]. The series and parallel resistances for the DJ, poly-Si, and stacking solar cells were analyzed and were shown in Table 3. Before mechanical stacking, the corresponding series resistances are $653 \Omega$ and $992 \Omega$ for the poly-Si and GaInP/GaAs DJ solar cells. After stacking, the series resistance was increased to $1889 \Omega$. The interconnect resistance from the in micro-metal ball was about $244 \Omega$, and the resulting shading loss was about $17.6 \%$. These characteristics can be improved by the efficiency of the direct metal bonding of the poly-Si on the crossing metals. Moreover, the $\eta$ values of the poly-Si, GaInP/GaAs DJ, and GaInP/GaAs/poly-Si TJ solar cells were $6.46 \%, 22.72 \%$, and $24.50 \%$, respectively. Once bonded, the GaInP/GaAs / poly-Si TJ solar cells, compared with the GaInP/GaAs DJ solar cells, had a conversion efficiency increase from $22.72 \%$ to $24.5 \%$. The $\mathrm{V}_{\text {oc }}$ of the GaInP/GaAs/poly-Si TJ solar cells, compared with that of the GaInP/GaAs DJ solar cells, increased from 2.18 V to $2.68 \mathrm{~V}$. Moreover, it was found that the drop of $\mathrm{V}_{\mathrm{oc}}$ of the GaInP/GaAs/poly-Si TJ solar cells compared to the sum of GaInP/GaAs DJ solar cells and poly-Si solar cell was $40 \mathrm{mV}$. Correspondingly, the drop of $\mathrm{V}_{\mathrm{oc}}$ of the GaInP/GaAs/poly-Si TJ solar cells compared to the sum of GaInP/GaAs DJ solar cells and single crystal Si solar cell was $140 \mathrm{mV}$. The difference comes from the different bonding. In our earlier publication (Ref. [17]), we used the wire bonding which resulted in the large $V_{\text {oc }}$ drop due to the low shunt resistance. This demonstrates that mechanical stacking is useful for increasing the conversion efficiency of multi-junction solar cells by the $\mathrm{V}_{\text {oc }}$. The results agreed well with those of a GaInP/GaAs DJ solar cell bonded to a single crystal Si solar cell [17]. 
Table 3. Series and parallel resistances of ploy-Si, GaInP/GaAs DJ and GaInP/GaAs/poly-Si triplejunction solar cells obtained from the J-V curve.

\begin{tabular}{ccc}
\hline Type & $\mathbf{R}_{\mathbf{s}}(\boldsymbol{\Omega})$ & $\mathbf{R}_{\mathbf{p}}(\boldsymbol{\Omega})$ \\
\hline Poly-Si solar cell & 653 & 976 \\
\hline GaInP/GaAs DJ solar cell & 992 & 57,142 \\
\hline GaInP/GaAs/poly-Si solar cell & 1889 & 52,356 \\
\hline
\end{tabular}

$\mathrm{R}_{\mathrm{s}}$ : series resistance; $\mathrm{R}_{\mathrm{p}}$ : parallel resistance.

Table 4 shows the comparison of mechanically Stacked Solar Cells with the epitaxial growth $6 \mathrm{~J} \mathrm{III-V} \mathrm{solar} \mathrm{cell} \mathrm{[2].} \mathrm{The} \mathrm{highest} \mathrm{efficiency} \mathrm{of} \mathrm{solar} \mathrm{cell} \mathrm{is} \mathrm{still} \mathrm{obtained} \mathrm{by} \mathrm{epitaxial}$ growth. The record efficiency of mechanically stacked GaInP/AlGaAs/Si solar cell is 30.8\% by palladium nanoparticles [32,34]. Although the efficiency is not high as the publication, it can be improved by using the high performance III-V and poly-Si solar cell. Moreover, the major issues in this study are the adhesive strength, series resistance and shading loss between the stacked cells. The adhesive strength can be improved by metal layers bonding, e.g., In/In, In/Sn or In/Au bonding. Not only, the series resistance can also be reduced. As concerning the shading loss, the dimension of connected electrode should be optimized. If the bonding is instead of metal bonding, it can be realized by industry, high efficiency solar cells can be produced and applied for green energy.

Table 4. Comparison of mechanically Stacked Solar Cells with the epitaxial growth 6J III-V solar cell.

\begin{tabular}{ccc}
\hline Type & Device Structure & Best Efficiency \\
\hline Epitaxial Growth & 6J III-V solar cells & $39.2 \%(\mathrm{AM} 1.5 \mathrm{~g})(2020)[2]$ \\
Palladium nanoparticles & GaAs/Si & $13.5 \%(2018)[33]$ \\
Palladium nanoparticles & TJ GaInP/AlGaAs/Si & $30.8 \%(2020)[34]$ \\
Two-terminal connect & TJ GaInP/GaAs//Si & $27.31 \%(2019)[18]$ \\
Two-terminal connect & TJ GaInP/GaAs//InGaAs & $26.95 \%(2019)[18]$ \\
In metal balls & TJ GaInP/GaAs/poly-Si & $24.5 \%$ (this work) \\
\hline
\end{tabular}

\section{Conclusions}

This study successfully employed a mechanical stacking technique involving the sprinkling of micro metal balls onto a metal line region using a high-optical-transmission spin-coated glue material to bond a GaInP/GaAs dual-junction (DJ) solar cell to a polysilicon solar cell. Moreover, the transmission results demonstrated that DJ GaInP/GaAs solar cells absorbed light at a wavelength of $300-880 \mathrm{~nm}$ and did not absorb light as the wavelength longer than $880 \mathrm{~nm}$. Thus, this part light from 880 to $1100 \mathrm{~nm}$ can be utilized by the bottom cell. GaInP/GaAs/poly-Si triple-junction (TJ) solar cells were observed to reach a conversion efficiency of $24.5 \%$, with an open-circuit voltage of $2.68 \mathrm{~V}$, a short-circuit current density of $12.39 \mathrm{~mA} / \mathrm{cm}^{2}$, and a fill factor of $73.8 \%$. Thus, combining the poly-Si solar cell with III-V DJ solar cell can subsequently improve the conversion efficiency of the TJ solar cell.

Author Contributions: The manuscript was completed through the contributions of all authors. R.-H.H. conceived the idea, Y.-C.K. developed it. P.-L.L., W.-C.W. and Y.-J.T. contributed to the calculation. Y.-C.K., A.S. and R.-H.H. contributed to the data analyses and prepared the manuscript. All authors have read and agreed to the published version of the manuscript.

Funding: This work was financially supported by the Ministry of Science and Technology (Taiwan, R.O.C.) under the Contract Nos. MOST 109-2634-F-009-028, 109-2221-E-009-143-MY3, 107-2221-E009-117-MY3, 109-2224-E-009-002, 110-2622-8-009-018-SB, 110-2218-E-A49-012-MBK and in part by the SPROUT Project-Center for Emergent Functional Matter Science of National Yang Ming Chiao Tung University. 
Data Availability Statement: Data is contained within the article.

Conflicts of Interest: The authors declare no competing financial and non-financial interests.

\section{References}

1. Geisz, J.F.; Steiner, M.A.; Jain, N.; Schulte, K.L.; France, R.M.; McMahon, W.E.; Perl, E.E.; Friedman, D.J. Building a Six-Junction Inverted Metamorphic Concentrator Solar Cell. IEEE J. Photovolt. 2018, 8, 626-632. [CrossRef]

2. Geisz, J.F.; France, R.M.; Schulte, K.L.; Steiner, M.A.; Norman, A.G.; Guthrey, H.L.; Young, M.R.; Song, T.; Moriarty, T. Six-junction III-V solar cells with $47.1 \%$ conversion efficiency under 143 Suns concentration. Nat. Energy 2020, 5, 326-335. [CrossRef]

3. Green, M.A.; Emery, K.; Hishikawa, Y.; Warta, W.; Dunlop, E.D. Solar cell efficiency tables (version 44). Prog. Photovolt. Res. Appl. 2014, 22, 701-710. [CrossRef]

4. Green, M.A.; Hishikawa, Y.; Dunlop, E.D.; Levi, D.H.; Hohl-Ebinger, J.; Yoshita, M.; Ho-Baillie, A.W. Solar cell efficiency tables (Version 53). Prog. Photovolt. Res. Appl. 2019, 27, 3-12. [CrossRef]

5. Saif, O.; Abouelatta, M.; Shaker, A.; Elsaid, M.K. On the optimization of InGaP/GaAs/InGaAs triple-junction solar cell. IOP Conf. Ser. Mater. Sci. Eng. 2018, 446, 012010. [CrossRef]

6. Archer, M.J.; Law, D.C.; Mesropian, S.; Boca, A.; Haddad, M.; Ladous, C.; King, R.R.; Atwater, H.A. GaInP/GaAs dual junction solar cells on Ge/Si epitaxial templates. Appl. Phys. Lett. 2008, 92, 103503. [CrossRef]

7. Wang, L.; Diaz, M.; Conrad, B.; Zhao, X.; Li, D.; Soeriyadi, A.; Gerger, A.; Lochtefeld, A.; Ebert, C.; Perez-Wurfl, I.; et al. Material and Device Improvement of GaAsP Top Solar Cells for GaAsP/SiGe Tandem Solar Cells Grown on Si Substrates. IEEE J. Photovolt. 2015, 5, 1800-1804. [CrossRef]

8. Grassman, T.J.; Chmielewski, D.J.; Carnevale, S.D.; Carlin, J.A.; Ringel, S.A. GaAs0.75P0.25/Si Dual-Junction Solar Cells Grown by MBE and MOCVD. IEEE J. Photovolt. 2016, 6, 326-331. [CrossRef]

9. Yaung, K.N.; Vaisman, M.; Lang, J.; Lee, M.L. GaAsP solar cells on GaP/Si with low threading dislocation density. Appl. Phys. Lett. 2016, 109, 032107. [CrossRef]

10. France, R.M.; Dimroth, F.; Grassman, T.J.; King, R.R. Metamorphic epitaxy for multijunction solar cells. MRS Bull. 2016, 41, 202-209. [CrossRef]

11. Chiu, P.; Law, D.; Woo, R.; Singer, S.; Bhusari, D.; Hong, W.; Zakaria, A.; Boisvert, J.; Mesropian, S.; King, R.; et al. 35.8\% space and $38.8 \%$ terrestrial 5J direct bonded cells. In Proceedings of the 2014 IEEE 40th Photovoltaic Specialist Conference (PVSC), Denver, CO, USA, 8-13 June 2014; pp. 11-13.

12. Dimroth, F.; Tibbits, T.N.D.; Niemeyer, M.; Predan, F.; Beutel, P.; Karcher, C.; Oliva, E.; Siefer, G.; Lackner, D.; Fus-Kailuweit, P.; et al. Four-Junction Wafer-Bonded Concentrator Solar Cells. IEEE J. Photovolt. 2016, 6, 343-349. [CrossRef]

13. Essig, S.; Allebé, C.; Remo, T.; Geisz, J.F.; Steiner, M.A.; Horowitz, K.; Barraud, L.; Ward, J.S.; Schnabel, M.; Descoeudres, A.; et al. Raising the one-sun conversion efficiency of III-V/Si solar cells to $32.8 \%$ for two junctions and $35.9 \%$ for three junctions. Nat. Energy 2017, 2, 17144. [CrossRef]

14. Akiyama, M.; Kawarada, Y.; Kaminishi, K. Growth of GaAs on Si by MOVCD. J. Cryst. Growth 1984, 68, 21-26. [CrossRef]

15. Tanabe, K.; Watanabe, K.; Arakawa, Y. III-V/Si hybrid photonic devices by direct fusion bonding. Sci. Rep. 2012, 2, 349. [CrossRef]

16. Essig, S.; Benick, J.; Schachtner, M.; Wekkeli, A.; Hermle, M.; Dimroth, F. Wafer-Bonded GaInP/GaAs//Si Solar Cells With 30\% Efficiency Under Concentrated Sunlight. IEEE J. Photovolt. 2015, 5, 977-981. [CrossRef]

17. Kao, Y.-C.; Chou, H.-M.; Hsu, S.-C.; Lin, A.; Lin, C.-C.; Shih, Z.-H.; Chang, C.-L.; Hong, H.-F.; Horng, R.-H. Performance comparison of III-V//Si and III-V//InGaAs multi-junction solar cells fabricated by the combination of mechanical stacking and wire bonding. Sci. Rep. 2019, 9, 4308. [CrossRef] [PubMed]

18. Essig, S.; Ward, S.; Steiner, M.A.; Friedman, D.J.; Geisz, J.F.; Stradins, P.; Young, D.L. Progress Towards a 30\% Efficient GaInP/Si Tandem Solar Cell. Energy Procedia 2015, 77, 464-469. [CrossRef]

19. Gee, J.M.; Virshup, G.F. A 31\%-efficient GaAs/silicon mechanically stacked, multijunction concentrator solar cell. In Proceedings of the Twentieth IEEE Photovoltaic Specialists Conference, Las Vegas, NV, USA, 26-30 September 1988; pp. 754-758.

20. Yang, J.; Peng, Z.; Cheong, D.; Kleiman, R. III-V on Silicon Multi-Junction Solar Cell with 25\% 1-Sun Efficiency via Direct Metal Interconnect and Areal Current Matching. In Proceedings of the 27th European Photovoltaic Solar Energy Conference and Exhibition, Frankfurt, Germany, 24-28 September 2012; pp. 160-163.

21. Soga, T.; Kato, T.; Yang, M.; Umeno, M.; Jimbo, T. High efficiency AlGaAs/Si monolithic tandem solar cell grown by metalorganic chemical vapor deposition. J. Appl. Phys. 1995, 78, 4196-4199. [CrossRef]

22. Takamoto, T.; Ikeda, E.; Kurita, H.; Ohmori, M. Over 30\% efficient InGaP/GaAs tandem solar cells. Appl. Phys. Lett. 1997, 70, 381-383. [CrossRef]

23. Yang, J.; Peng, Z.; Cheong, D.; Kleiman, R. Fabrication of High-Efficiency III-V on Silicon Multijunction Solar Cells by Direct Metal Interconnect. IEEE J. Photovolt. 2014, 4, 1149-1155. [CrossRef]

24. Tayagaki, T.; Makita, K.; Tachibana, T.; Mizuno, H.; Oshima, R.; Takato, H.; Sugaya, T. Three-Terminal Tandem Solar Cells With a Back-Contact-Type Bottom Cell Bonded Using Conductive Metal Nanoparticle Arrays. IEEE J. Photovolt. 2020, 10, 358-362. [CrossRef]

25. Kuphal, E. Phase diagrams of InGaAsP, InGaAs and InP lattice-matched to (100) InP. J. Cryst. Growth 1984, 67, 441-457. [CrossRef]

26. Lee, C.; Yu, A.; Yan, L.; Wang, H.; He, J.H.; Zhang, Q.X.; Lau, J.H. Characterization of intermediate In/Ag layers of low temperature fluxless solder based wafer bonding for MEMS packaging. Sens. Actuators A Phys. 2009, 154, 85-91. [CrossRef] 
27. Horng, R.-H.; Lu, Y.-A.; Wuu, D.-S. Light Extraction Study on Thin-Film GaN Light-Emitting Diodes With Electrodes Covering by Wafer Bonding and Textured Surfaces. IEEE Trans. Electron Devices 2010, 57, 2651-2654. [CrossRef]

28. Horng, R.-H.; Shen, K.-C.; Kuo, Y.-W.; Wuu, D.-S. GaN light emitting diodes with wing-type imbedded contacts. Opt. Express 2012, 21, A1-A6. [CrossRef] [PubMed]

29. Mizuno, H.; Makita, K.; Matsubara, K. Electrical and optical interconnection for mechanically stacked multi-junction solar cells mediated by metal nanoparticle arrays. Appl. Phys. Lett. 2012, 101, 191111. [CrossRef]

30. Yablonovitch, E.; Hwang, D.M.; Gmitter, T.J.; Florez, L.T.; Harbison, J.P. Van der Waals bonding of GaAs epitaxial liftoff films onto arbitrary substrates. Appl. Phys. Lett. 1990, 56, 2419-2421. [CrossRef]

31. Meitl, M.A.; Zhu, Z.; Kumar, V.; Lee, K.J.; Feng, X.; Huang, Y.Y.; Adesida, I.; Nuzzo, R.G.; Rogers, J.A. Transfer printing by kinetic control of adhesion to an elastomeric stamp. Nat. Mater. 2005, 5, 33-38. [CrossRef]

32. Baba, M.; Makita, K.; Mizuno, H.; Takato, H.; Sugaya, T.; Yamada, N. Effect of Series Resistances on Conversion Efficiency of GaAs/Si Tandem Solar Cells With Areal Current-Matching Technique. IEEE J. Photovolt. 2018, 8, 654-660. [CrossRef]

33. Wu, F.-L.; Ou, S.-L.; Horng, R.-H.; Kao, Y.-C. Improvement in separation rate of epitaxial lift-off by hydrophilic solvent for GaAs solar cell applications. Sol. Energy Mater. Sol. Cells 2014, 122, 233-240. [CrossRef]

34. Makita, K.; Mizuno, H.; Tayagaki, T.; Aihara, T.; Oshima, R.; Shoji, Y.; Sai, H.; Takato, H.; Müller, R.; Beutel, P.; et al. III-V / /Si multijunction solar cells with $30 \%$ efficiency using smart stack technology with Pd nanoparticle array. Prog. Photovolt. Res. Appl. 2019, 28, 16-24. [CrossRef] 